\title{
Etnografi Komunikasi Komunitas yang Kehilangan Identitas Sosial dan Budaya di Kabupaten Cilacap
}

\author{
S. Bekti Istiyanto ${ }^{1}$ dan Wiwik Novianti ${ }^{2}$ \\ ${ }^{1,2}$ Universitas Jenderal Soedirman
}

\begin{abstract}
ABSTRAK
Penelitian ini dilakukan didasari oleh kekhawatiran bahwa warisan budaya di Desa Rejodadi Cimanggu secara bertahap lenyap pada generasi muda. Karena itu, masyarakat berupaya membangun identitas budaya dan sosial dengan menciptakan sebuah komunitas yang mewakili identitas mereka yang telah dianggap mulai pudar. Tujuan dari penelitian ini adalah untuk mengetahui dan menganalisis: perilaku komunikasi seharihari masyarakat Rejodadi sebagai masyarakat tutur, dan mengidentifikasi identitas sosial dan budaya dalam kehidupan komunitas yang berbeda-beda namun tetap bisa eksis berdampingan secara harmonis. Penelitian ini menggunakan Teori Identitas Sosial dari Henri Tajfel dan John Turner sebagai dasar acuan. Metode penelitian kualitatif yang dilakukan dalam penelitian ini menggunakan pendekatan etnografi komunikasi. Sedangkan dalam pengumpulan data, penelitian ini menggunakan observasi partisipan, wawancara, dokumentasi berupa gambar dan rekaman, serta data review yang berkaitan dengan masyarakat desa Rejodadi. Ada 15 responden yang terlibat dalam penelitian ini sebagai informan. Mereka adalah warga desa Rejodadi yang mengetahui dengan baik tentang permasalahan penelitian. Hasil penelitian ini menunjukkan bahwa penggunaan bahasa dalam proses komunikasi masyarakat Rejodadi dilakukan secara fleksibel disesuaikan dengan partner berbicara; Proses komunikasi sehari-hari terjadi secara alami, jujur, dan seimbang tanpa meninggalkan nilai-nilai pengajaran, rasa hormat dan kasih sayang; Komunitas basa Paurangan didirikan sebagai bentuk yang mewakili masyarakat Paurangan Cimanggu; upaya melestarikan dan mewarisi nilai budaya dan sosial dilakukan dalam bentuk penguatan identitas budaya dan sosial masyarakat Paurangan.
\end{abstract}

Kata-kata Kunci: Basa paurangan; berjalan harmonis; etnografi komunikasi; identitas budaya; identitas sosial

\section{Ethnography Communication of Community Who Lost Social and Cultural Identity in Cilacap}

\begin{abstract}
This research was conducted based on the concern that the cultural heritage of Rejodadi Village in Cimanggu gradually vanished in the younger generation. Therefore, the community strives to build social and cultural identity by creating a community that represents the identity of those who have considered starting to fade. The purpose of this research is to find out and analyze everyday communication: behavior society as society Rejodadi said, and identified the social and cultural identity in the life of different communities while remaining can exist side by side in harmony. This research uses the Social Identity Theory of Henri Tajfel and John Turner as a basis of reference. Methods of qualitative research conducted in this study using ethnographic approach to communication. While in data collection, research using observation, interviews, participant documentation in the form of pictures and footage, as well as a review of data pertaining to the community of the village of Rejodadi. There are 15 respondents involved in this research as informants. They are the citizens of the village of Rejodadi who know well about the problems of research. The results of this study showed that the use of the language in the communication process Rejodadi community perpetrated flexibly adapted to the partner speaks; The daily communication process occurs naturally balanced, honest, and without leaving the teaching of values, respect and affection; The community of Paurangan was established as a base form that represents the community Paurangan Cimanggu; Preservation and inherit the value of the cultural and social identity forms done in strengthening the community's social and cultural Paurangan.
\end{abstract}

Keywords: Basa paurangan; communication ethnography; cultural identity; exist harmoniously; social identity

Korespondensi: Dr. S. Bekti Istiyanto, S.Sos., M.Si., Program Studi Magister Ilmu Komunikasi Fisip Universitas Jenderal Soedirman. JL. Profesor Doktor H. R. Boenyamin, No. 993, 53122, Grendeng, Purwokerto Utara, Kabupaten Banyumas, Jawa Tengah 53122.Email: bektiis@yahoo.com 


\section{PENDAHULUAN}

Sebagai manusia sosial, tidaklah mungkin seseorang dilepaskan dari lingkungan sosial budaya asalnya. Latar belakang inilah yang memberikan identitas diri dalam berperilaku dan berinteraksi dengan orang lain, khususnya ketika mereka berkomunikasi dengan orangorang yang berbeda budaya.

Perilaku budaya yang bersumber dari identitas budaya asli seharusnya menentukan bahasa dan perilaku komunikasi yang digunakan oleh orang tersebut, dan mampu membedakannya dengan perilaku orang lain yang budayanya berbeda. Artinya, seseorang akan berperilaku sesuai latar belakang budayanya masing-masing dan akan mempunyai ciri khas yang berbeda dengan orang lain yang berbeda budaya pula. Menurut Henri Tajfel dan John Turner sebagai penemu Teori Identitas Sosial yang mendefinisikan identitas sosial sebagai pengetahuan individu dimana seseorang merasa sebagai bagian anggota kelompok yang memiliki kesamaan emosi serta nilai (Hogg \& Abrams, 1988). Ciri khas unik yang berbeda dengan yang lain sebagai sebuah identitas sosial dan budaya ini seharusnya ada individu dalam setiap komunitas tertentu.

Kondisi yang unik dan sedikit berbeda dengan yang seharusnya terjadi justru berlangsung dalam komunitas masyarakat berbeda budaya yang tinggal berdekatan secara geografis. Sebagai contoh adalah yang terjadi di antara masyarakat yang tinggal di desa-desa terluar dari Kabupaten Cilacap Provinsi Jawa Tengah yang semestinya berbudaya asli Jawa dalam berinteraksi sosialnya. Desa-desa ini tercakup sebagai daerah Kabupaten Cilacap bagian barat yang meliputi Kecamatan Dayeuh Luhur, Wanareja, Majenang dan Cimanggu.

Mayoritas anggota masyarakat di daerah tersebut seolah-olah telah kehilangan jati diri asli sosial budayanya. Maksud kehilangan jati diri asli sosial budayanya adalah masyarakat di sini berperilaku budaya tidak merujuk secara tegas sumber budaya asli mana yang seharusnya mereka pegang dan warisi dari para orang tua atau leluhur mereka yaitu budaya dan bahasa Jawa. Mereka mencampurkan bahasa, perilaku budaya bahkan nilai-nilai keyakinan dalam kehidupan mereka berdasar pola kebutuhan keseharian dan kemudahan mereka untuk berinteraksi di antara mereka. Budaya mereka bukanlah merujuk kepada budaya Jawa dengan keunikan-keunikan tersendiri. Penggunaan bahasa sebagai media berkomunikasi sebagai contohnya dalam logat, dialek dan pemaknaan atas istilah-istilah tertentu terasa berbeda dengan bahasa Jawa.

Interaksi antara masyarakat tersebut dengan masyarakat berbudaya Sunda dalam kehidupan sehari-hari juga sangat tidak mungkin dihindarkan. Pengaruh bahasa dan budaya Sunda bagi mereka merupakan sebuah kelaziman yang berlaku secara alami. Secara geografis tempat tinggal antarmasyarakat berbeda budaya ini tidaklah terlalu jauh sehingga mereka tetap dapat saling bertegur sapa, berinteraksi dan membangun kerja sama dengan mudah di antara kedua masyarakat berbeda budaya tersebut. Ketersediaan transportasi umum yang melewati daerah di antara keduanya dan kedekatan geografis bagi mereka semakin menjadi kemudahan untuk saling berkomunikasi dan secara tidak langsung memengaruhi kebudayaan yang mereka pegang masing-masing.

Desa Rejodadi Kecamatan Cimanggu, sebenarnya cukup jauh jaraknya dengan masyarakat berbahasa dan berbudaya Sunda di Kotamadaya Banjar Provinsi Jawa Barat. Dengan jarak kurang lebih $35 \mathrm{~km}$ dari garis perbatasan kedua provinsi, semestinya budaya dan bahasa Jawa (Banyumasan) yang lebih digunakan seperti yang pada umumnya berlaku di Kabupaten Banyumas atau Kabupaten Cilacap lainnya (bagian timur). Namun ternyata ada keunikan yang terjadi pada masyarakat di desa ini. Ada kekhasan berbahasa yang dipegang teguh secara turun temurun di antara kebanyakan anggota masyarakatnya. Hal inilah yang membedakan masyarakat Rejodadi secara khusus dan secara umum Cimanggu dengan masyarakat-masyarakat lain di Kabupaten Cilacap.

Di sinilah yang menjadi menarik dan urgen untuk diteliti khususnya terkait dengan harmonisnya identitas sosial dan budaya yang muncul dari masyarakat berbeda budaya tanpa menimbulkan konflik horizontal dengan identitas sosial dan budaya masyarakat di sekitarnya. Berbeda dengan beberapa konflik yang muncul atas dasar ras atau suku di Indonesia, di wilayah ini identitas sosial dan budaya justru mampu hidup secara harmonis. Berdasarkan latar belakang penelitian ini maka 
dapat diidentifikasi permasalahan penelitian sebagai berikut: "Bagaimana etnografi komunikasi yang terjadi pada masyarakat Desa Rejodadi Kecamatan Cimanggu Kabupaten Cilacap dapat menjadi sebuah identitas sosial dan budaya secara harmonis?".

Untuk memosisikan penelitian ini penulis menjadikan artikel dalam jurnal yang ditulis oleh Mahali dan Saamah (2013) yang menjelaskan tentang unsur hewan yang ada dalam peribahasa Suku Semai. Suku Semai ini merupakan pengamat alam yang baik dan menjadikan khazanah hutan sebagai bahan terbaik untuk menyatakan rasa, kehendak dan dijadikan sebagai perbandingan dengan sifat atau perlakuan manusia. Khazanah hutan yang kaya ini menyebabkan kiasan bahasa milik suku kaum Semai merujuk kepada sifat hewan dan tumbuhan sebagai bahan persamaan dan perbandingan dengan sifat manusia.

Penelitian ini menggunakan kerangka etnografi komunikasi dengan empat topik utama pembahasannya yaitu uraian tentang situasi, pemakaian, struktur dan fungsi aktivitas pertuturan tersebut. Perbedaan utamanya adalah pada fokus permasalahan, lokasi penelitian, nilai dan norma yang dianut oleh masyarakat. Suku Semai bersumber pada alam sementara dalam penelitian ini berfokus pada bahasa dan kebudayaan yang terjadi penyatuan sebagai sebuah identitas sosial.

Artikel lain yang dipublikasikan oleh Debebe (2008) membahas sikap komunikasi efektif dan tidak efektif masyarakat Anglo Navajo dalam hubungan antarorganisasi sebagai bagian tindakan individu yang dominan dalam sebuah grup politik. Hasil lain yang terungkap adalah koordinasi lintas budaya yang efektif dalam hubungan antarorganisasi tersebut membutuhkan petunjuk dari aturan yang berbasis kekuasaan. Gelaye Debebe membicarakan beberapa pola komunikasi dalam etnografi komunikasi seperti yang diungkap oleh Hymes (dalam Kuswarno, 2008) tentang kompeten dan inkompeten serta dasar budaya sebagai representasi kelompok yang dominan secara politik yang telah menjadi sebuah identitas sosial.

Layaknya dua sisi mata uang, budaya dan komunikasi mempunyai hubungan timbal balik. Hall (1959), mengatakan bahwa culture is communication dan communication is culture. Budaya merupakan bagian dari perilaku komunikasi dan pada gilirannya komunikasi pun turut menentukan, memelihara, mengembangkan, atau mewariskan budaya. Porter dan Samovar (Mulyana \& Rakhmat: 2005, 26) menyatakan bahwa hubungan reciprocal (timbal balik) antara budaya dan komunikasi penting untuk dipahami bila ingin mempelajari komunikasi antarbudaya secara mendalam. Hal ini terjadi karena melalui budayalah orangorang dapat belajar berkomunikasi.

Porter dan Samovar (Mulyana \& Rakhmat, 2005) kembali menegaskan bahwa kemiripan budaya dalam persepsi akan memungkinkan pemberian makna yang cenderung mirip pula terhadap suatu realitas sosial atau peristiwa tertentu. Sebagaimana seseorang yang memiliki latar belakang budaya yang berbeda-beda maka dengan sendirinya akan memengaruhi cara dan praktik berkomunikasi orang tersebut.

Martin dan Nakayama (2004: 97-99) mengulas bagaimana komunikasi memengaruhi budaya. Dijelaskan, bahwa budaya tidak akan bisa terbentuk tanpa komunikasi. Pola-pola komunikasi yang tentunya sesuai dengan latar belakang dan nilai-nilai budaya akan menggambarkan identitas budaya seseorang. Banyak aspek atau unsur dari budaya yang dapat memengaruhi perilaku komunikasi seseorang. Pengaruh tersebut muncul melalui suatu proses persepsi dan pemaknaan suatu realitas.

Perilaku-perilaku komunikasi yang sudah terbangun dan terpola sedemikian rupa akan melahirkan suatu karakteristik khas yang akan membentuk suatu kebiasaan atau budaya komunikasi bagi suatu komunitas budaya tertentu. Karena itu, aktivitas komunikasi dari seorang anggota budaya tertentu dapat merepresentasikan kepercayaan, nilai, sikap dan bahkan pandangan dunia dari budayanya itu. Selain itu, melalui komunikasi dapat pula memperkuat nilai-nilai dasar dan esensial dari suatu budaya.

Hasil percampuran dua budaya yang berbeda seperti yang terjadi di sebagian besar masyarakat desa-desa di Kecamatan Cimanggu Kabupaten Cilacap dapat dikatakan telah menjadi sebuah kebudayaan tersendiri karena mencakup semua komponen dalam definisidefinisi yang banyak diungkapkan oleh para ahli. Hal ini juga mencakup persoalan bahasa 'baru' sebagai hasil percampuran dua bahasa yang berbeda (Bahasa Jasun atau sering disebut oleh anggota masyarakat Cimanggu sebagai 
Basa Paurangan).

Littlejohn (2010: 194) menggambarkan bahwa etnografi komunikasi adalah aplikasi metode etnografi terhadap pola-pola komunikasi dalam sebuah kelompok. Di sini seorang pengamat (intepreter) berusaha untuk memahami bentuk-bentuk komunikasi yang dilakukan oleh para anggota kelompok atau budaya. Komunikasi budaya bisa berbeda dalam berbagai bentuk tetapi semua bentuk komunikasi mempunyai bagian terhadap pemaknaan kode, komunikator mengetahui dan menggunakan kode, saluran-saluran komunikasi, suasana, bentuk pesan, topik dan kejadian yang bisa dibentuk dari pesan.

Menurut Kuswarno (2008), etnografi komunikasi bertujuan untuk menghimpun data deskriptif dan analisis terhadapnya tentang bagaimana makna-makna sosial dipergunakan (dalam konteks komunikasi) atau ketika makna itu dipertukarkan. Sebagai sebuah langkah penelitian etnografi komunikasi akan menghasilkan deskripsi etnografis tentang bagaimana 'cara-cara berbicara' dan saluran komunikasinya, digunakan dalam masyarakat yang berbeda-beda (Novianti, 2014). Tidaklah mengherankan bila sebuah penelitian etnografi komunikasi dianggap sebagai penelitian yang menyeluruh atau holistik karena mencakup semua aspek dan sering dikenal dengan story telling yang hasilnya sangat tebal sebagai gambaran yang kaya (thick description).

Sebagai dasar seseorang akan melakukan penelitian etnografi komunikasi, maka Kuswarno (2008: 38-46) menyebutkan ada beberapa pijakan dasar yang secara jelas tidak dapat ditinggalkan yaitu: (1) masyarakat tutur, (2) aktivitas komunikasi, (3) komponen komunikasi, (4) kompetensi komunikasi, dan (5) varietas bahasa. Spradley (2007: xiii) mengungkapkan bahwa melalui bahasa atau lebih khusus lagi melalui daftar kata-kata yang ada dalam satu bahasa akan mampu memperoleh budaya yang ada dalam pikiran manusia dan organisasi pikirannya tentang fenomena material. Di sinilah kajian etnografi baru memulai asumsinya melalui aliran antropologi kognitif yang menyebutkan bahwa setiap masyarakat mempunyai satu sistem yang unik dalam memersepsikan dan mengorganisasikan fenomena material, seperti benda-benda, kejadian, perilaku dan emosi. Termasuk dalam hal ini adalah persoalan budaya itu sendiri.
Bahasa merupakan komponen utama dalam etnografi komunikasi selain budaya dan pola komunikasi. Spradley (2007: 25-33) menjelaskan bahwa fokus perhatian etnografi komunikasi adalah perilaku komunikasi dalam tema kebudayaan tertentu namun bukan keseluruhan perilaku. Perilaku komunikasi dalam etnografi komunikasi adalah perilaku dalam konteks sosial kultural (Kuswarno, 2008: 35-36).

Kondisi masyarakat Desa Rejodadi secara khusus dan masyarakat Kecamatan Cimanggu bagian utara secara umum dapat menggambarkan konsep tentang etnografi komunikasi atas situasi sosial budaya yang terjadi di dalamnya. Sebagai masyarakat yang seharusnya beridentitas budaya dan berbahasa Jawa karena berada di dalam kewilayahan Provinsi Jawa Tengah, akan tetapi dalam kesehariannya terjadi keunikan yang dapat membedakannya dengan masyarakat Jawa (Banyumasan) pada umumnya yang ada di sekitar mereka.

Sebagai masyarakat tutur, masyarakat Desa Rejodadi mempunyai kaidah-kaidah tersendiri yang membedakan dengan masyarakat tutur Jawa yang telah dikenal pada umumnya atau telah menjadi sebuah sub masyarakat tutur baru. Akan tetapi kekhasan masyarakat tutur yang dipunyai dan digunakan oleh masyarakat ini sudah mempunyai corak khusus yang berbeda dengan masyarakat tutur Jawa yang lain. Seperti penggunaan bahasa yang lebih terkesan merupakan sebuah hasil bentuk akulturasi dan enkulturasi budaya yang telah berjalan dalam waktu yang sangat lama.

Adapun tujuan penelitian ini adalah untuk mengetahui dan menganalisis: perilaku komunikasi masyarakat Rejodadi sebagai masyarakat tutur, kegiatan komunikasi seharihari, relativitas bahasa yang digunakan untuk membentuk pola komunikasi baku, serta mengidentifikasi identitas budaya dan sosial dalam kehidupan komunitas yang berbeda-beda namun tetap bisa eksis berdampingan secara harmonis di desa Rejodadi.

\section{METODE PENELITIAN}

Metode yang digunakan dalam penelitian ini adalah metode kualitatif etnografi komunikasi. Metode ini dipilih karena dapat menggambarkan, menjelaskan dan membangun 
hubungan dari kategori-kategori dan data yang ditemukan. Kondisi ini sesuai dengan tujuan dari studi etnografi komunikasi untuk menggambarkan, menganalisis dan menjelaskan perilaku komunikasi dari suatu kelompok sosial (Kuswarno, 2008: 86). Sesuai pendapat Hymes (dalam Littlejohn, 2010: 194) maka penelitian ini melihat pola komunikasi dengan anggotanya, berbicara dengan komunitas, situasi berbicara, kejadian waktu berbicara, komponen kegiatan berbicara, aturan berbicara dan fungsi bicara dalam komunitas.

Fokus penelitian ini adalah mengkaji, memahami secara menyeluruh dan mendalam bagaimana perilaku komunikasi masyarakat Desa Rejodadi Kecamatan Cimanggu Kabupaten Cilacap sebagai masyarakat tutur yang terjadi secara alamiah, bagaimana aktivitas proses komunikasi keseharian masyarakat yang terjadi, bagaimana relativitas bahasa yang digunakan dapat berfungsi sebagai sebuah pola komunikasi yang baku. Kajian berikutnya adalah bagaimana sebuah identitas sosial dapat terbentuk di antara perbedaan budaya dan bahasa yang ada pada masyarakat sekitarnya di wilayah Cimanggu dan bagaimana proses pewarisan identitas sosial tersebut dapat terjadi kepada generasi berikutnya.

Subjek penelitian ini adalah masyarakat yang tinggal di Desa Rejodadi Kecamatan Cimanggu Kabupaten Cilacap. Sedangkan objek penelitian ini adalah masyarakat Desa Rejodadi sebagai masyarakat tutur dan proses (aktivitas) komunikasi masyarakat Desa Rejodadi. Dalam proses pengumpulan data di lapangan, penulis menggunakan sebanyak 15 informan yang merupakan tokoh-tokoh masyarakat Desa Rejodadi, memahami permasalahan penelitian yang ingin dijawab, dan dapat menggunakan bahasa khas Cimanggu yaitu Basa Paurangan.

Untuk mengumpulkan data dalam penelitian ini menggunakan participant observe atau pengamatan berperan serta dengan introspeksi, wawancara mendalam, dan telaah dokumen. Untuk menguji kemantapan dan keabsahan data yang telah berhasil dikumpulkan, penelitian ini menggunakan teknik triangulasi data. Menurut Patton, triangulasi data adalah usaha membandingkan dan mengecek balik derajat kepercayaan suatu informasi yang diperoleh melalui waktu dan alat yang berbeda dalam metode kualitatif (dalam Moleong, 2010: 330). Dalam penelitian ini, peneliti menggunakan triangulasi sumber dengan cara membandingkan data hasil pengamatan di lokasi penelitian dengan hasil wawancara dari para informan, juga membandingkan hasil wawancara dengan isi suatu dokumen seperti data demografis Desa Rejodadi, dokumen keanggotaan komunitas Sunda Paurangan, notulensi hasil pertemuan pengurus komunitas Sunda Paurangan, dan sumber sekunder berupa data sejarah dari Dinas kebudayaan Provinsi Jawa Barat dan Jawa Tengah.

\section{HASIL DAN PEMBAHASAN}

Sebagai sebuah masyarakat tradisional yang mempunyai identitas yang berbeda dengan identitas masyarakat lainnya, masyarakat Desa Rejodadi sebagai bagian dari masyarakat Paurangan Cimanggu, tidaklah bisa dilepaskan dari kompleksitas hubungan antarmanusia di dalamnya. Dengan posisi geografis desa yang strategis karena dilalui sarana transportasi nasional, sedikit banyak membawa pengaruh kepada situasi interaksi masyarakatnya. Interaksi dapat terjadi dengan sesama anggota masyarakat Rejodadi sendiri dan juga dengan masyarakat yang mempunyai budaya dan bahasa yang berbeda. Interaksi tersebut dilakukan baik di antara sesama anggota masyarakat Rejodadi dan dengan masyarakat di luar Cimanggu.

Interaksi merupakan sebuah keadaan yang tidak dapat dielakkan oleh masyarakat Rejodadi. Dengan kondisi yang terbatas dalam persoalan ekonomi yaitu kesempatan mendapatkan lapangan kerja yang memadai dan fasilitas pendidikan yang minim, mengharuskan sumber daya manusia di Desa Rejodadi untuk keluar wilayahnya. Proses untuk mendapatkannya tersebut yang membuat masyarakat Desa Rejodadi harus berinteraksi dengan masyarakat lain.

Dalam proses berkomunikasi, seorang anggota warga Desa Rejodaditidak dapat dibatasi dalam sebuah identitas tertentu yang secara tegas membedakan dengan identitas budaya lainnya. Karena kebutuhan berkomunikasi tersebut tidak mungkin hanya terjadi dengan pemilik identitas budaya yang sama saja, tetapi meluas sifat dan cakupannya kepada siapa saja komunikasi tersebut harus dilakukan. Meski berbeda budaya dan bahasa untuk saling mengerti isi pesan yang disampaikan saat berkomunikasi, diperlukan kesamaan kaidah sekaligus kesamaan variasi 
linguistik untuk dapat memahami isi pesan yang disampaikan masing-masing. Hal ini sesuai seperti pendapat yang disampaikan oleh Hymes (dalam Syukur, 1994: 264).

Kesamaan kaidah dan variasi linguistik seperti pendapat Hymes di atas menjelaskan bahwa komunikasi merupakan sebuah aktivitas simbolis, dimana penggunaan simbol-simbol yang diubah dalam ke dalam kata-kata (verbal) untuk ditulis dan diucapkan atau simbol-simbol nonverbal untuk diperagakan (Liliweri, 2013: 5). Proses saling bertukar simbol-simbol dalam proses berkomunikasi akan ditujukan kepada sejauh mana tingkat keberhasilan diperoleh. Tingkat keberhasilan sendiri berbentuk kesamaan makna yang dipertukarkan masingmasing pelaku. Kesamaan makna inilah yang menjadi ukuran akhir keberhasilan sebuah komunikasi, sementara pertukaran simbol adalah sebagai media penyampaian isi pesan. Keberadaan bahasa menjadi penting karena digunakan sebagai ukuran penyamaan makna dari proses pertukaran simbol dalam komunikasi yang terjadi.

Bahasa merupakan sebuah simbol yang kompleks. Sebagai simbol yang kompleks, bahasa dibentuk dari proses pengkombinasian dan pengorganisasian simbol-simbolnya hingga memiliki arti khusus yang berbeda dengan arti simbol yang lain. Kemampuan berbahasa inilah yang dapat membedakan seseorang dari orang lain, masyarakat satu dengan masyarakat lainnya. Bahasa inilah yang dapat menyatukan atau memisahkan manusia dari kelompoknya atau satu masyarakat dengan masyarakat lainnya (Burke dalam Littlejohn dan Foss, 2009: 169).

Pada peristiwa-persitiwa komunikasi sehari-hari yang teramati, peranan bahasa yang digunakan dalam pergaulan sehari-hari menunjukkan ada perbedaan yang jelas bagi masyarakat Desa Rejodadi dengan masyarakat lain. Identitas budaya dimunculkan dalam proses penyampaian bahasa yang terlihat mencampurkan sumber-sumber bahasa lain di sekitarnya dan hal ini tidak terjadi dalam masyarakat berbudaya dan berbahasa Jawa maupun Sunda.

Terlihat betul proses pemisahan identitas masyarakat disebabkan oleh penggunaan Basa Paurangan yang biasa digunakan masyarakat di wilayah Cimanggu. Masyarakat luar dapat membedakan identitas budaya masyarakat Paurangan dengan hanya melihat bahasa yang mereka tuturkan. Hal ini selaras dengan pendapat Burke di atas. Ketika mereka berbicara dengan bahasa yang sama dengan sesama anggota masyarakat Cimanggu mereka dapat diidentifikasi sebagai bagian dari masyarakat Paurangan. Berbeda ketika mereka berbicara dengan masyarakat berbahasa lain semisal bahasa Jawa Banyumasan, kerancuan identitas sebagai masyarakat Paurangan atau sebagai masyarakat Cilacap akan sulit dipisahkan.

Persoalan identitas sosial dan budaya sebagai masyarakat Paurangan tetaplah menjadi fokus dan perhatian secara khusus. Mereka beranggapan bahwa identitas masyarakat mereka sebenarnya berbeda atau mempunyai perbedaan dengan anggapan masyarakat di sekitar mereka selama ini. Pendapat ini didasari oleh kuatnya akar sejarah yang menjadikan mereka mempunyai keunikan dan ciri khas tertentu yang berbeda dari masyarakat Cilacap pada umumnya. Mereka meyakini bahwa mereka merupakan bagian dari masyarakat masa lalu di bawah kekuasaan kerajaan Galuh Purba dan bukan berasal dari kekuasaan kerajaan Mataram Jawa yang berpusat di Yogyakarta.

Masyarakat Paurangan lebih merasa sebagai bagian dari masyarakat Galuh Purba yang kurang mendapat perhatian lebih dari masyarakat di luar mereka, termasuk dari pemerintah daerah tingkat dua dan tingkat satu maupun pemerintah pusat. Dengan keunikan bahasa dan budaya yang khas, mereka tetap dapat hidup berbaur dengan semestinya bahkan dapat menjadi sebuah potensi kewilayahan yang khas.

Bagi seseorang yang tidak mengetahui Basa Sunda Paurangan maka akan lebih mudah menunjuk mereka sebagai bagian dari masyarakat Cilacap karena bahasa Jawa Banyumasan yang digunakan bercampur dengan kata-kata dalam bahasa Sunda Paurangan. Karena itu menjadi hal yang wajar, masyarakat Paurangan di Cimanggu akan lebih bangga dengan identitas budaya masyarakatnya dilihat ketika mereka menggunakan Basa Paurangan sebagai bahasa pergaulan di antara anggota masyarakat.

Selain sebagai pemisah identitas sebuah masyarakat seperti pendapat Burke, dengan tegas Sapir-Whorf mengajukan hipotesis bahwa bahasa akan memengaruhi cara berpikir seseorang atau caranya memandang dunia (Liliweri, 2013: 152). Hipotesa bahwa 
bahasa dapat memengaruhi cara berpikir seseorang dapat diamati pada peristiwaperistiwa komunikasi sehari-hari masyarakat Rejodadi. Salah satu buktinya dapat terlihat dalam pandangan kesederajatan (egaliter) posisi pelaku komunikasi tanpa melihat terlebih dahulu pada awalnya status sosial dan ekonominya, meskipun situasi komunikasi yang terbangun tetap tidak meninggalkan norma kesopanan antara orang tua terhadap yang lebih muda atau sebaliknya. Konsep pandangan kesederajatan berkomunikasi ini diwujudkan sebagai bentuk kasih sayang dari yang lebih tua kepada yang di bawahnya, sebaliknya sebagai perwujudan penghormatan dari yang lebih muda kepada yang di atasnya. Semuanya dapat memahami penggunaan bahasa sesuai kebutuhan komunikasi yang terjadi dalam setiap kesempatan (Istiyanto, 2014).

Kondisi di atas juga ditunjang dengan kemampuan berbahasa yang tidak tunggal bagi masyarakat Paurangan Cimanggu. Secara sederhana mereka pasti bisa menggunakan bahasa ibu mereka yaitu Basa Paurangan dan dalam tuntutan interaksi dengan masyarakat lain mereka juga bisa menggunakan bahasa Jawa Banyumasan seperti mereka (khususnya generasi muda dan mengenyam pendidikan) menguasai bahasa Indonesia ketika ada pihak komunikasinya menggunakan bahasa tersebut dalam proses penyampaian pesan kepada mereka.

Setiap orang dapat memiliki banyak bahasa yang dikuasai, dan digunakan tergantung dengan siapa orang tersebut berkomunikasi dan kemampuan penguasaan bahasa yang dimilikinya. Hal ini nampak pada kemampuan berbahasa masyarakat Desa Rejodadi. Dengan sering terjadinya persinggungan dengan budaya dan bahasa lain di sekitar kehidupan mereka, menjadikan kemampuan berbahasa bukanlah terletak pada satu ukuran saja tetapi berkembang dengan perubahan-perubahan atau penyesuaian-penyesuaian tertentu. Kemampuan untuk memiliki dan menggunakan berbagai varietas bahasa ini seringkali diterapkan secara tidak sadar sebagai akibat dari proses sosialisasi dan enkulturasi kebudayaan yang terjadi pada mereka (Kuswarno, 2008: 46).

Kemampuan untuk mempunyai perbedaan variasi bahasa seperti yang sering dilakukan oleh masyarakat Desa Rejodadi ini merupakan hal yang rumit, namun dapat dijelaskan bahwa adanya kemampuan tersebut didasari oleh faktor kesejarahan yang khas. Desa Rejodadi merupakan desa yang dapat dikatakan terbagi dalam dua kategorisasi masyarakatnya. Di sebelah utara desa masyarakatnya diwarisi budaya dan bahasa Sunda Kuna karena hubungan sejarah dengan masa lalu sebagai bagian dari masyarakat kerajaan Galuh Purba di Ciamis. Sedangkan di sebelah selatan desa mayoritas merupakan masyarakat pendatang terutama dari daerah 'wetan' yaitu daerahdaerah di timur Cilacap seperti Yogyakarta dan Kebumen yang berbudaya dan berbahasa Jawa baik bersumber dari sub bahasa Jawa Yogyakarta maupun sub bahasa Jawa Banyumasan. Pertemuan dua budaya dan bahasa inilah yang mendasari penguasaan bahasa yang menjadi kekhasan bahasa percakapan masyarakat Desa Rejodadi dan umumnya masyarakat Paurangan Cimanggu.

Percampuran bahasa dalam komunikasi masyarakat sebenarnya merupakan sebuah kelaziman pada masyarakat perbatasan wilayah yang berbeda budaya seperti Desa Rejodadi. Dalam kenyataannya Desa Rejodadi berjarak cukup jauh, sekitar $35 \mathrm{~km}$ dari perbatasan Jawa Barat yang berbudaya dan berbahasa Sunda. Karenanya, klaim atas bahasa yang digunakan masyarakat Desa Rejodadi di bagian utara bukan disebut sebagai bahasa Sunda lagi, sebutan bahasa yang digunakan oleh kebanyakan masyarakat Jawa Barat. Mereka lebih suka menyebut istilah bahasa Sunda Paurangan atau Basa Paurangan saja sebagai istilah atas nama bahasa yang mereka gunakan. Bahasa inilah yang sebenarnya mereka gunakan dalam berkomunikasi sehari-hari. Sebuah variasi bahasa yang berbeda namun mengandung banyak serapan kata-kata dari bahasa Sunda, bahasa Jawa (Banyumasan) dan bahasa-bahasa lainnya.

Keunikan penggunaan bahasa seperti yang ada pada masyarakat Desa Rejodadi menjadikan mereka sebagai sebuah kelompok sosial tersendiri yang berbeda dengan kelompok sosial yang lain. Dengan kaidah-kaidah tertentu dalam berbicara menjadikan masyarakat Desa Rejodadi dapat digolongkan sebagai sebuah masyarakat tutur yang mempunyai pola komunikasi tertentu.

Menurut Hymes (dalam Kuswarno, 2008), masyarakat tutur tidak saja sama-sama memiliki kaidah untuk berbicara, tetapi juga satu variasi 
lingustik. Saville-Troike membicarakan level analisis dimana masyarakat tutur tidak harus memiliki satu bahasa tetapi memiliki kaidah yang sama dalam berbicara. Masyarakat tutur menurut Saville-Troike (2003: 16) tidak hanya akan membagi isi pesannya dalam satu bahasa saja tetapi dikarenakan adanya peranan yang berbeda dari seorang pembicara berbahasa tertentu ke dalam masyarakat berbahasa jamak (lebih dari satu bahasa), maka akan menjadikan bahasa yang disampaikan akan menyesuaikan secara tunggal pula seperti yang digunakan oleh masyarakat.

Saville-Troike (2003) membagi tipologi dari masyarakat tutur secara informal dengan istilah "shoft-shelled" dan "hard-shelled" yaitu pembedaan dari dasar kekuatan batasan yang dipertahankan oleh sebuah bahasa. "Shoftshelled" lebih bermakna kepada penggunaan bahasa yang umum digunakan karena diketahui oleh orang banyak (termasuk pihak luar), dimana interaksi menggunakan bahasa itu lebih mudah diterima. Sedangkan "hard-shelled" lebih menekankan kepada pembicaraan yang lebih terbatas pembagiannya, karena ada pembatasan yang lebih tegas. Interaksi antara anggota masyarakat dengan pihak luar dalam tipologi ini berjalan dengan interaksi yang sangat minimal, namun langkah ini justru akan mampu menyediakan penjagaan bahasa dan budaya mereka dari pengaruh luar.

Dalam proses pertukaran pesan dari masing-masing pelaku peristiwa komunikasi yang diamati, semua pihak menunjukkan pesan-pesan verbal berupa kata-kata sesuai bahasa yang mereka gunakan. Perbedaan keterampilan berbahasa yang dimiliki tidak menyebabkan kegagalan untuk memahami pesan. Hal ini ditunjang dengan pemakaian pesan-pesan nonverbal baik dengan gerakan muka atau facial, gerakan sebagian tubuh atau gestur, kedekatan jarak pelaku atau proksemik, pakaian dan aksesoris tubuh yang menunjang komunikasi atau artifaktual, nada bicara dan intonasi atau parabahasa yang disesuaikan dengan konteks komunikasi yang terjadi.

Proses penyampaian pesan-pesan baik verbal maupun nonverbal merupakan bentukbentuk pertukaran pesan dalam interaksi pelaku-pelakunya. Secara teoretis bentuk pertukaran simbol antarmanusia yang diberi makna disebut dengan interaksi simbolik. Hal ini disebut Mulyana (2003: 68) sebagai esensi interaksi simbolik. Sebagai sebuah kehidupan sosial setiap manusia pastilah membutuhkan interaksi dengan sesamanya dan kehidupan sosial pada dasarnya merupakan interaksi manusia menggunakan simbol-simbol.

Teori interaksi simbolik, yang pertama kali dikenalkan oleh Herbert Blumer dan bersumber dari George Herbert Mead, merupakan teori yang melandasi dan mendukung etnografi komunikasi seperti yang dilakukan dalam metode penelitian ini. Khususnya terkait dengan kedudukan bahasa, kebudayaan dan komunikasi. Dimana melalui bahasa dan komunikasi merupakan pembentuk sebuah masyarakat dan kebudayaan (Kuswarno, 2008: 20). Dalam proses komunikasi maka terjadi pertukaran pesan melalui simbol bahasa sebagai medianya. Peranan komunikasi dan bahasa dalam pembentukan masyarakat dan kebudayaan inilah yang dikaji etnografi komunikasi seperti yang dilakukan dalam penelitian ini. Kuswarno (2008: 38-46) menyebutkan lima dasar pijakan dalam melakukan penelitian etnografi komunikasi yaitu: keberadaan masyarakat tutur, aktivitas komunikasi yang terjadi, komponen komunikasi, kompetensi komunikasi dan varietas bahasa yang digunakan.

Pada kasus masyarakat Desa Rejodadi sebagai masyarakat tutur selain bisa berbahasa Paurangan, biasanya mereka mampu berbicara dalam bahasa Jawa Banyumasan dan bahasa Indonesia terutama generasi muda dan mendapatkan pendidikan. (Berbeda dengan mereka yang berusia lanjut kemampuan berbahasa Indonesia masih tergolong rendah pada beberapa tingkatannya). Dalam kesehariannya seringkali ketiga bahasa tersebut bercampur pada satu waktu tergantung kepada siapa mereka berkomunikasi saat itu. (Hal ini terlihat jelas dalam hasil penelitian pada sub bab sebelumnya). Kondisi komunikasi yang seperti demikian tidaklah dapat disalahkan karena memang mereka sebagai sebuah masyarakat tutur dapat terbagi sebagai sebuah sub-sub masyarakat tutur (Kuswarno, 2008: 40). Kesamaan bahasa yang digunakan akan bergantung kepada penggunaan variasi bahasa yang dipunyai seperti yang diuraikan oleh Hymes.

Dalam tipologi informal versi SavilleTroike, masyarakat tutur Desa Rejodadi lebih menggunakan "shoft-shelled" dikaitkan kepada siapa yang menjadi lawan komunikasinya. 
Bila lawan bicara mereka bukanlah anggota masyarakat tutur Paurangan akan lebih memahami isi pesan dalam komunikasi dengan bahasa yang mencampurkan beberapa unsurnya atau bisa disebut sebagai bahasa pasaran. Dalam pembicaraan, umumnya masyarakat akan menggunakan bahasa Jawa Banyumasan dan Basa Sunda Paurangan secara acak dan campur. Hal ini terlihat dalam hasil penelitian komunikasi sehari-hari seperti proses pembicaraan antara mbah Riyadi dengan bapak Tasno, pembicaraan saat terjadi panen raya ikan, pembicaraan di dalam Mushola Al Hidayah, dan peristiwa komunikatif penjual dan pembeli jajanan anak di kios jajan Pasar Cileumeuh.

Penggunaan variasi bahasa masyarakat Desa Rejodadi seperti terlihat dalam hasil penelitian, dapat dibedakan tipologinya bila sebuah komunikasi terjadi hanya antara sesama penutur Basa Paurangan atau mereka masyarakatpendatang yanghanya menggunakan bahasa Jawa Banyumasan saja. Pada proses komunikasi ini akan lebih menekankan kepada tipologi "hard-shelled" karena pembicaraan hanya diketahui oleh masing-masing pelaku komunikasi. Secara tidak disadari terdapat fungsi penjagaan terhadap bahasa yang digunakan bagi pelakunya dan hal ini dapat dikatakan telah menjadi sebuah bentuk dari proses pewarisan bahasa ibu kepada masyarakat penuturnya.

Pijakan kedua untuk membahas etnografi komunikasi masyarakat tutur Desa Rejodadi adalah adanya aktivitas komunikasi. Aktivitas komunikasi dapat diidentifikasikan sebagai peristiwa komunikasi yang terjadi yang biasanya terjadi secara khas dan berulang serta dapat dibedakan dengan proses komunikasi yang lain.

Sebagai masyarakat tradisional, masyarakat Desa Rejodadi dapat digolongkan sebagai masyarakat yang terbuka dalam arti bersedia melakukan komunikasi dengan siapa pun tanpa didasari oleh adanya suatu imbalan dalam bentuk-bentuk tertentu. Berdasarkan pengamatan peneliti, klasifikasi masyarakat Desa Rejodadi sekarang ini terdata dalam dua kelompok masyarakat berjumlah penduduk terbanyak yaitu berada dalam kelompok anakanak dan orang tua. Sementara angkatan muda yang menjadi angkatan kerja produktif lebih banyak yang meninggalkan desa untuk merantau ke luar daerah. Kondisi tersebut berimplikasi dalam hal aktivitas komunikasi yang terjadi, dimana lebih banyak diamati dilakukan oleh sesama orang tua atau antara anak-anak dengan orang tua.

Aktivitas komunikasi menurut Hymes (dalam Kuswarno, 2008: 41) menjelaskan tiga hal yaitu situasi komunikatif atau konteks terjadinya komunikasi, peristiwa komunikasi atau keseluruhan perangkat komponen yang utuh, dan adanya tindak komunikatif. Dalam aktivitas komunikasi masyarakat Desa Rejodadi situasi komunikasi terjadi dalam semua keadaan, tidak saja dalam pertemuanpertemuan formal seperti di balai desa atau pelayanan pos kesehatan desa akan tetap dalam segala tempat dan waktu seperti saat perjalanan menuju tempat kerja, di pasar tradisional bahkan di tempat pemandian umum sekalipun. Situasi komunikasi terjadi secara alami, mengalir sesuai kebutuhan komunikasi itu sendiri dan berhubungan dengan semua pihak yang berada dalam situasi komunikasi tersebut.

Dalam peristiwa atau konteks komunikasi masyarakat tutur Desa Rejodadi yang terjadi, terdapat perangkat-perangkat yang utuh dengan adanya tujuan peristiwa komunikasi tersebut dilakukan, topik pembicaraan yang jelas meski tidak diungkap atau dinyatakan di awal pembicaraan, dan para pelaku komunikasi sebagai partisipan aktifnya. Di dalam peristiwa komunikasi yang diamati dalam penelitian, varietas bahasa yang digunakan pun dalam bentuk yang sama yaitu penggunaan bahasa khas Cimanggu yang seperti mencampurkan antara Basa Sunda Paurangan, bahasa Jawa Banyumasan dan terkadang dengan bahasa Indonesia. Hal ini seperti terlihat dalam semua peristiwa komunikasi yang teramati dalam penelitian.

Dalam persoalan tindak komunikatif, semua aktivitas komunikasi yang terjadi dapat menghasilkan bentuk-bentuk isi pesan seperti penegasan isi pesan seperti yang terjadi dalam aktivitas komunikasi di tempat pemandian umum agar berhati-hati dalam menjaga anakanak mereka khususnya bila permainan mereka berhubungan dengan api. Bentuk lain adalah informasi seperti aktivitas komunikasi sapaan antara mbah Riyadi dengan bapak Tasno tentang waktu datangnya kegiatan panen raya ikan. Pernyataan dan perintah dari aktivitas komunikasi seperti yang terlihat dalam pembicaraan di Mushola Al Hidayah antara 
imam sholat kepada anak-anak yang menjadi makmum sholat maghrib berjama'ah. Dalam bentuk-bentuk pesan nonverbal juga dapat dilihat bahwa semua aktivitas komunikasi yang dilakukan menggunakan bentuk-bentuk yang disepakati secara umum seperti gerakan tangan, perubahan wajah, perhatian, kedekatan jarak, intonasi pembicaraan, hingga membangun kesamaan situasi pembicaraan dengan muncul simpati dan empati bersama.

Secara umum gambaran peristiwa komunikasi yang menjadi komponen terpenting dalam etnografi komunikasi dapat dihasilkan sebuah model pola komunikasi seperti yang ditunjukkan pada gambar 1. Berdasarkan pada model pola komunikasi yang telah dihasilkan maka dapat dianalisis bahwa pola komunikasi yang ada atau berhasil diperoleh di lapangan penelitian akan lebih memudahkan penemuan hubungan-hubungan khas antarkomponen pembentuk satu peristiwa komunikasi. Hal ini berdasarkan kepada pendapat Kuswarno (2008: 42). Dalam pola komunikasi masyarakat tutur yang berhasil didapatkan di Desa Rejodadi terlihat bahwa aktivitas komunikasi yang terjadi secara alami dan seimbang di antara pelaku-pelakunya, menggunakan pesan-pesan verbal dan nonverbal yang dapat diartikan secara umum (disepakati dalam masyarakat) maknanya, penggunaan varietas bahasa yang menyesuaikan dengan para pelakunya, dan akhirnya menghasilkan tindak-tindak komunikatif yang diharapkan sesuai tujuan dan topik komunikasi yang ada.

Dalam pembahasan tentang komponen komunikasi masyarakat tutur Desa Rejodadi telah diuraikan dalam hasil penelitian secara lengkap. Dengan komponen-komponen komunikasi yang telah diurai tersebut maka identifikasi sebuah peristiwa komunikasi akan dapat dijelaskan. Identifikasi peristiwa komunikasi dalam hasil penelitian didasari

Aktivitas Komunikasi Masyarakat Tutur Desa Rejodadi:

- Terjadi secara alami

- Lebih bersifat jujur dan apa adanya

- Tanpa pamrih imbalan tertentu

- Mengalir sesuai kebutuhan komunikasi

- Berjalan secara seimbang di antara partisipannya

Konteks Komunikasi

1. Formal: pertemuan di balai desa dan di PKD, pertemuan Posyandu

2. Informal: di jalan, di pasar tradisional, di mushola, saat memanen ikan, di tempat pemandian umum
Peristiwa Komunikasi:

1. Bertujuan

2. Mempunyai topik khusus pembicaraan

3. Ada partisipan yang sederajat

4. Kesamaan varietas bahasa yang digunakan

Tindak Komunikatif:

Berupa pernyataan, informasi, perilaku nonverbal yang disepakati, penegasan atau pesan peringatan. 
atas pendapat Syukur (1994: 208-209) yang menguraikan sebelas komponen sebagai berikut: tipe peristiwa komunikasi, topik inti, tujuan dan fungsi, setting, pelaku peristiwa komunikasi, bentuk pesan yang ada, isi pesan yang disampaikan, urutan tindakan, kaidah interaksi yang diterapkan, norma-norma interpretasi, dan terakhir hubungan antarkomponen komunikasi yang ada.

Dasar pijakan yang keempat dalam pembahasan ini adalah persoalan kompetensi komunikasi. Sebagai sebuah masyarakat tutur yang berinteraksi tidak hanya kepada sesama anggota masyarakat Desa Rejodadi, akan tetapi juga kepada masyarakat di luar desa, mengharuskan pelaku komunikasi memiliki keterampilan yang memadai. Menurut pendapat Syukur (1994: 26) terdapat tiga keterampilan dasar yang harus dipunyai suatu masyarakat tutur yaitu keterampilan berbahasa, keterampilan berinteraksi dan keterampilan kebudayaan. Bila salah satu keterampilan tersebut tidak dipunyai oleh masyarakat tutur maka akan menghasilkan gagalnya perilaku komunikasi yang akan dibangun.

Pada keterampilan berbahasa yang dipunyai oleh masyarakat tutur Desa Rejodadi, secara umum mereka mampu menggunakan varietas bahasa yang disesuaikan kepada siapa mereka berkomunikasi. Kemampuan untuk menggunakan bahasa baik Jawa Banyumasan, Sunda Paurangan ataupun Indonesia kepada pihak yang tepat menunjukkan keterampilan berbahasa yang menjadi dasar bagi keberhasilan sebuah komunikasi.

Keterampilan penggunaan bahasa yang menyesuaikan ini bersifat dinamis dan selalu mengalami perubahan alami. Dalam kenyataan yang ditemukan di Desa Rejodadi masih berlaku aturan norma menyampaikan bahasa kepada pihak-pihak tertentu seperti aturan kesopanan berbicara antara anak-anak kepada orang tua yang telah mereka kenal. Berlaku dengan pendekatan yang sama, maka pembicaraan akan lebih tidak mengindahkan tata kesopanan berbahasa atau bahasa umum sehari-hari bila para pelakunya dalam kedudukan yang sederajat dalam strata sosial atau usia. Demikian juga antara anak-anak dengan orang tua, namun ada perbedaan kelas bahasa yang akan digunakan oleh anak-anak yang tidak terlalu mengenal orang tua yang diajak berkomunikasi, maka anak-anak akan lebih memilih sikap dan bahasa yang lebih halus seperti kelas bahasa dalam bahasa Jawa Banyumasan atau bahasa Indonesia.

Dalam penyampaian pesan-pesan verbal dan nonverbal dalam komunikasi seharihari yang dilakukan masyarakat tutur Desa Rejodadi, kesemuanya berlandaskan kepada kesamaan makna yang disepakati berlaku secara umum di masyarakat. Meskipun dalam wawancara mendalam selanjutnya ditemukan ada perbedaan makna bila disamakan dengan padanan kata yang menjadi sumber asalnya. Sebagai contoh, kata ngewekeun dalam bahasa Sunda dimaknai sebagai persetubuhan yang cenderung tabu diucapkan masyarakat, sementara dalam Basa Paurangan dimaknai sebagai menikahkan atau menghadiri undangan pernikahan. Sebagai perbandingan kata tersebut dalam bahasa Jawa disebut sebagai ngunduh mantu. Kata bobogohan justru menjadi kata yang tabu diucapkan masyarakat Desa Rejodadi juga masyarakat Paurangan lainnya di Cimanggu, karena bermakna sebagai persetubuhan sementara dalam bahasa Sunda kata tersebut dimaknai dengan arti berkasihkasihan (membina hubungan; berpacaran).

Dalam persoalan struktur sosial, masyarakat Desa Rejodadi sebagai masyarakat tradisional masih memperhitungkan tata nilai kepada siapa mereka berinteraksi. Hal ini bahkan telah menjadi sebuah nilai sikap yang ditunjukkan dalam interaksi sehari-hari masyarakatnya. Dalam pengamatan peneliti memang hal tersebut sangat dimungkinkan terjadi. Penyebab utama yang memungkinkan hal tersebut terjadi karena adanya jarak usia yang cukup jauh di kebanyakan masyarakat Desa Rejodadi sendiri. Dimana interaksi antara anak-anak kepada orang tua akan lebih menekankan untuk menurut, mengikuti dan bersifat sub ordinat. Sebaliknya komunikasi antara orang tua kepada anak lebih bersifat mendidik, mengajarkan, memperingatkan, menasehati, dan menakutnakuti atau mengancam.

Kemungkinan untuk terjadi perubahan nilai akibat interaksi anggota masyarakat yang merantau di luar daerah dengan budaya baru, sebenarnya juga menjadi hal yang sangat mungkin terjadi. Bagaimanapun dalam interaksinya warga Desa Rejodadi yang merantau kebanyakan berusia muda yang berdasar pendapat para tokoh masyarakat desa, sangat rentan untuk terpengaruh dengan nilai- 
nilai baru yang dibawa dari daerah rantaunya. Perubahan ini bisa terjadi tidak hanya dalam cara menyampaikan pesan, gaya berkomunikasi, struktur bahasa hingga perubahan tata nilai baik nilai kesopanan maupun norma-norma sosial.

Bagi para tokoh masyarakat akan lebih mudah mewariskan nilai-nilai sosial, budaya dan juga bahasa secara khusus kepada anakanak yang masih tinggal dalam lingkungan masyarakat desa dibandingkan dengan yang sudah pernah merantau ke luar daerah. Di sinilah diperlukan keterampilan berbudaya masyarakat tutur desa Rejodadi dalam proses enkulturasi kebudayaannya sendiri. Mengikuti pendapat Rani (2004: 63), enkulturasi mengacu kepada pewarisan budaya dan pewarisan budaya mendekati pewarisan biologis. Artinya, enkulturasi dapat terjadi pada proses pembelajaran dari orang tua, orang dewasa atau teman sebaya. Dengan kata lain pewarisan budaya merupakan proses pembelajaran budaya terhadap seseorang baik melalui pendidikan ataupun keluarga. Enkulturasi terjadi di lingkungan budaya yang sama dan akan berhasil jika seseorang dapat mewarisi budayanya baik bahasa, nilai-nilai maupun acara ritual.

Pembahasan terakhir masyarakat tutur desa Rejodadi berhubungan dengan masalah varietas bahasa yang digunakan. Menurut Hymes (dalam Kuswarno, 2008: 45) dalam setiap masyarakat tutur terdapat varietas kode bahasa (language code) dan cara-cara berbicara yang bisa dipakai oleh anggota masyarakatnya atau disebut sebagai repertoir komunikatif masyarakat tutur. Variasi ini mencakup semua varietas dialek atau tipe yang digunakan masyarakat tutur.

Pada masyarakat desa Rejodadi sebagai masyarakat tutur memang terdapat varietas bahasa dalam penggunaannya sehari-hari, khususnya antara bahasa Sunda dan bahasa Jawa Banyumasan. Dalam kesehariannya, proses komunikasi di desa Rejodadi terbagi dalam dua situasi. Masyarakat di sebelah selatan desa lebih memakai bahasa Jawa Banyumasan sebagai bahasa pergaulannya. Agak berbeda dengan di sebelah utara desa yang kebanyakan masyarakatnya menggunakan Basa Paurangan. Bahasa ini sudah ada karena merupakan warisan generasi-generasi sebelumnya dan tertransmisikan dalam proses enkulturasi yang sangat lama. Secara umum hingga kini bahasa ini digunakan di semua wilayah Cimanggu, termasuk di Desa Rejodadi khususnya di bagian utara desa.

Keberadaan Basa Paurangan sendiri sering dianggap sebagai sebuah sub bahasa Sunda dialek tenggara (Gunawan, 2012). Akan tetapi dalam wawancara berikutnya ditemukan pendapat dari para informan bahwa kedudukan sebagai sub bahasa tersebut hanya didasarkan kepada kemiripan bahasa dan bukan atas dasar sumber kesejarahan. Ditambah dengan data keterbatasan jumlah penutur Basa Paurangan yang ada sekarang ini dan semakin menyempitnya lokasi masyarakat penuturnya, membuat bahasa ini terasa semakin terpinggirkan. Meskipun demikian penjagaan bahasa ini sebagai bahasa ibu masyarakat tutur asli Desa Rejodadi dan umumnya masyarakat Cimanggu masih dipertahankan. Hal tersebut dilakukan secara alami oleh para tokoh masyarakat dan penutur Basa Paurangan kepada generasi muda.

Kegiatan penjagaan dan pelestarian bahasa tersebut dapat dimasukkan sebagai proses sosialisasi dan enkulturasi kebudayaan. Kegiatan ini dimunculkan dalam beberapa kegiatan antara lain: pembuatan buku kamus bahasa Sunda Paurangan, kegiatan seni dalam komunitas, pembiasaan berbicara menggunakan bahasa Sunda Paurangan daripada bahasa Banyumasan atau bahasa Indonesia, dan kontak anggota komunitas dalam media sosial.

Proses sosialisasi dan enkulturasi kebudayaan masyarakat tutur Desa Rejodadi yang terpenting, ternyata dilakukan secara tidak sadar karena sifatnya yang alami dan mengalir sebagai sebuah bahasa pergaulan masyarakat sehari-hari seperti saat bertemu di jalan atau saling kontak di media sosial. Bahkan ada aturan dalam media sosial wajib menggunakan bahasa mereka, bila ada yang melanggar maka akan diberi sanksi dari ditegur hingga dikeluarkan dari grup komunitas. Proses berjalan dalam peristiwa komunikasi masyarakatnya dan memunculkan hasil tindak komunikatif sesuai keadaan. Kondisi inilah yang menjadi kaidah pemilihan bahasa yang dihasilkan oleh masyarakat tutur Desa Rejodadi, khususnya saat berkomunikasi dengan masyarakat yang berbeda budaya dan bahasa, tetap dapat berjalan dan terjaga meski mengalami keterbatasan dan hambatan dalam praktik kesehariannya. Perjalanan dan penjagaan bahasa tersebut ke depannya diharapkan dapat menjadi identitas budaya khas mereka sendiri. 


\section{SIMPULAN}

Berdasarkan kepada pembahasan maka dapat dikemukakan beberapa hal sebagai kesimpulan antara lain: Perilaku komunikasi masyarakat di Desa Rejodadi Kecamatan Cimanggu Kabupaten Cilacap mempunyai keunikan khas sebagai masyarakat tutur dan ini menjadi sebuah identitas sosial dan budaya yang unik. Peristiwa komunikasi yang terjadi di desa ini bersifat perorangan dan juga kelompok yang terasa lebih formal, serta terjadi dalam keseharian aktivitas warga Desa Rejodadi. Perilaku komunikasi sehari-hari masyarakat Desa Rejodadi dapat menggambarkan adanya persinggungan dua identitas sosial yang ada pada masyarakat Cimanggu pada umumnya. Perilaku komunikasi masyarakat sehari-hari yang terjadi di Desa Rejodadi berlangsung secara khas dalam bertukar pesan, dimana terjadi percampuran kata-kata dan istilahistilah dalam percakapan yang menyesuaikan dengan kebutuhan pemaknaan isi pesan dalam komunikasi itu sendiri. Aktivitas komunikasi masyarakat yang terjadi umumnya berlangsung dalam posisi sederajat (egaliter), jujur, bersifat alami, tanpa mempunyai tujuan material tertentu. Aktivitas komunikasi dapat dilakukan di semua tempat dan waktu, berhubungan dengan semua orang, dan berlangsung menggunakan pesan verbal dan nonverbal. Untuk bahasa yang digunakan dalam aktivitas komunikasi, para pelakunya menyesuaikan dengan kemampuan bahasa pihak yang menjadi lawan bicaranya.

Bahasa sebagai unsur kebudayaan nonmaterial mewujud dalam beberapa varietasnya. Akan tetapi semuanya ada dan bercampur tergantung pada keterampilan pelaku komunikasi dan dilandasi pada kesamaan kaidah penggunaannya. Keterampilan penggunaan bahasa masyarakat Desa Rejodadi akan menentukan keberhasilan peristiwa komunikasi yang dilakukan. Kemampuan dalam berbahasa ini diwariskan kepada generasi berikutnya melalui proses enkulturasi yang telah berjalan dalam waktu yang lama dan berlangsung secara harmonis.

Hasil penelitian ini jelas membawa unsur kebaruan (novelty) yaitu berupa pengertian tentang penciptaan sebuah identitas sosial dan budaya pada masyarakat yang mampu berjalan secara harmonis tanpa menimbulkan konflik antarbudaya yang terjadi di Indonesia. Berbeda dengan munculnya gesekan antarbudaya di beberapa wilayah lain Indonesia, maka penelitian ini dapat menjadi rujukan terbaru bahwa berbeda budaya tidak selalu diidentikkan dengan perpecahan atau permusuhan. Penelitian ini juga bermanfaat karena dapat memberikan nilai kepada masyarakat yang berbeda budaya bahwa melalui proses akulturasi yang baik melalui pola komunikasi yang tepat di antara pelakunya akan mampu menghasilkan sebuah pola komunikasi yang harmonis pula. Secara konseptual teoretis penelitian ini mampu menjadi rujukan penelitian sejenis khususnya penelitian etnografi komunikasi yang mampu berjalan dengan damai serta menghasilkan pola komunikasi yang khas sebagai identitas sosial masyarakat.

Sebagai saran untuk penelitian selanjutnya dapat dilakukan tentang bagaimana hasil yang diperoleh setelah komunitas ini nantinya eksis, apakah bisa menjadi sebuah pola komunikasi baku seperti diharapkan sehingga identitas sosial dan budaya mereka dapat dipertahankan atau justru akan menjadi sebuah identitas yang baru yang sama sekali berbeda dari identitasidentitas sosial budaya yang ada sebelumnya.

\section{DAFTAR PUSTAKA}

Hall, E. T. (1959). The silent language. New York: Anchor Books.

Istiyanto, S. B. (2014). Membangun identitas di antara dua budaya. Bandung: Hasil Penelitian.

Gelaye, D. (2008). Cross-cultural competence and power-based rules: a native american case study. International Journal of Intercultural Relations 32. 2008: 399-414.

Gunawan, G. G. (2012). Bahasa sunda?. Diakses dari http://www.diciamis.com/ bahasa-sunda.php Februari 2018.

Hogg, M. A. \& Dominic, A. (1988). Social identification. London and New York: Routledge.

Kuswarno, E. (2008). Metode penelitian komunikasi etnografi komunikasi. Bandung: Widya Padjadjaran.

Liliweri, A. (2013). Makna budaya dalam komunikasi antarbudaya. Yogyakarta: LKiS.

Littlejohn, S. W. (2010). Theories of human communication. California: Belmont.

Littlejohn, S. W \& Foss, K. (2009). Theories 
of human communication. California: Belmont.

Mahali, S. N. \& Saamah, M. R. (2013). Haiwan sebagai perlambangan dalam peribahasa orang semai. Journal of Language Studies 83 Volume 13 (1), February 2013.

Martin, J. N. \& Nakayama, T. K. (2004). Intercultural communication in contexts. United States: The McGraw-Hill Companies.

Moleoeng, L. J. (2010). Metode penelitian kualitatif. Bandung: Remaja Rosdakarya.

Mulyana, D. (2003). Metodologi penelitian kualitatif: paradigma baru ilmu komunikasi dan ilmu sosial lainnya. Bandung: Remaja Rosdakarya

Mulyana, D. \& Rakhmat, J. (2005). Komunikasi antarbudaya, panduan berkomunikasi dengan orang-orang berbeda budaya. Bandung: Remaja Rosdakarya.

Novianti, E. (2014). Pola komunikasi pasangan antaretnik sunda-minang di bandung. Jurnal Kajian Komunikasi, Volume 2, No. 2, Desember 2014, hlm 161-172.

Rani. A. (2004). Komunikasi lintas budaya antara etnik cina dan etnik aceh di kota banda aceh. Disertasi: Universitas Padjadjaran.

Saville-Troike, M. (2003). The ethnography of communication. an introduction. Oxford UK: Blackwell Publishing.

Spradley, J. P. (2007). Metode etnografi. Yogyakarta: Tiara Wacana.

Syukur, A. I. (1994). Panduan penelitian etnografi komunikasi. Surabaya: Penerbit Usaha Nasional. 